\title{
Uterine blood flow and prostaglandin levels in ovariectomized rabbits
}

\author{
R. Antonini, G. Valenzuela and M. J. K. Harper \\ The Center for Research and Training in Reproductive Biology, Department of Obstetrics and \\ Gynecology, The University of Texas Health Science Center at San Antonio, 7703 \\ Floyd Curl Drive, San Antonio, Texas 78284, U.S.A.
}

\begin{abstract}
Summary. Blood flow (measured by radioactive microspheres) through the uteri of ovariectomized rabbits increased significantly by $2 \mathrm{~h}$, was lower at 4 and $8 \mathrm{~h}$, and returned to control values by $24 \mathrm{~h}$ after an injection of $25 \mu \mathrm{g}$ oestradiol-17ß. Blood flow through the kidneys was not affected. Concentrations of PGF and PGE in uterine vein blood were elevated after oestrogen treatment. PGF values were significantly greater than control. PGE concentrations, while elevated, were not significantly different from control, although the pattern of release was similar to that of PGF. Pretreatment of animals with progesterone or L11204, or concurrent treatment with indomethacin did not modify the blood flow through the uterus. It is concluded that the increased uterine blood flow seen after oestrogen treatment is not related to prostaglandin production.
\end{abstract}

\section{Introduction}

Oestrogen is known to increase total uterine blood flow in non-pregnant ovariectomized ewes within 2 h (Rosenfeld, Killam, Battaglia, Makowski \& Meschia, 1973). Oestrogen is also known to elevate peripheral prostaglandin (PG) $\mathrm{F}$ levels within $12 \mathrm{~h}$ of administration on Day 13 of an artificial cycle in similar animals (Caldwell, Tillson, Brock \& Speroff, 1972), and to elevate PGF in uterine vein blood, concomitant with increased blood flow through the uterus, within $90 \mathrm{~min}$ in ewes with transplanted uteri (Barcikowski, Carlson, Wilson \& McCracken, 1974). Information on the pattern of secretion of PGF and PGE after oestrogen treatment could establish a role of PGs in modulating and/or causing the effects of oestrogen on preimplantation stages of pregnancy (Greenwald, 1963; Chang \& Yanagimachi, 1965; Chang \& Harper, 1966; Chang, 1966; Greenwald, 1967). We have therefore measured total uterine blood flow and PGE and PGF levels in uterine vein blood of ovariectomized rabbits before and after oestrogen administration.

\section{Materials and Methods}

\section{Animals}

Mature New Zealand White rabbits $(3.5-4.5 \mathrm{~kg})$ were anaesthetized by i.v. injection of $30 \mathrm{mg}$ pentobarbitone sodium (Diamond Labs) and bilateral ovariectomy was performed. The rabbits were allowed to recover for 2-3 weeks before being used for experiment.

Blood flow was measured by the microsphere method of Janson (1975). The specifications of the labelled microspheres (Nuclear Products, St Paul, Minnesota) were as follows: isotope, ${ }^{85} \mathrm{Sr}$ : particle size, $15 \pm 5 \mu \mathrm{m}$ : sp. act. $12.93 \mathrm{mCi} / \mathrm{g}$ in a $10 \%$ dextran solution which was diluted $1: 20$ with $20 \%$ dextran and then two drops of Tween 20 were added. The solution was subjected to sonication and $1 \mathrm{ml}$ containing approximately $1.7 \times 10^{6}$ microspheres was injected into each rabbit. The rabbits were anaesthetized with pentobarbitone sodium and a polyethylene catheter (i.d. $0 \cdot 11 \mathrm{~cm}, 0 . \mathrm{d} .0 \cdot 16 \mathrm{~cm}$ ) was inserted into the left carotid artery until the tip reached the left ventricle. A polyethylene catheter (i.d. $0.08 \mathrm{~cm}$, o.d. $0.12 \mathrm{~cm}$ ) was placed in the right femoral artery and attached to a Buchler polystatic pump which was calibrated to withdraw blood at a constant speed of $1.8 \mathrm{ml} \mathrm{min}^{-1}$. A dose of 2000 units heparin sodium (Upjohn Co.) was given to each animal and the microspheres were injected 
slowly over $30 \mathrm{sec}$ into the left ventricle. Blood was collected for $30 \mathrm{sec}$ before, $30 \mathrm{sec}$ during and $30 \mathrm{sec}$ after injection from the femoral artery. The organ to be studied was then removed, trimmed, blotted, weighed, and the whole organ counted in a gamma counter (Beckman 300). In uterine and kidney tissue the number of microspheres trapped in the organ was never less than about 4000 , giving measurements within $5 \%$ of the mean at a $95 \%$ confidence level. By contrast, only approximately 400 spheres were trapped in the oviducts of ovariectomized untreated rabbits and this did not permit reliable measurements of blood flow through this organ. Perfusion $\left(\mathrm{ml} \mathrm{min}^{-1} \mathrm{~g}^{-1}\right)$ through the organ was calculated according to the formula $(n \times p) /(q \times w)$, where $p=$ no. of spheres in the organ; $\mathrm{q}=$ no. of spheres in the reference blood sample; $\mathrm{n}=\mathrm{ml} \mathrm{min}^{-1}$ at which reference blood sample was taken; and $w=$ weight of organs in grams.

\section{Experiments}

Blood flow was studied in 3-4 rabbits/group at different times after the subcutaneous administration of $25 \mu \mathrm{g}$ oestradiol-17 3 (Schering) in $0.5 \mathrm{ml}$ cotton seed oil. Three other groups were studied at 2 and $12 \mathrm{~h}$ after injection of $25 \mu \mathrm{g}$ oestradiol and received (a) progesterone (Proluton: Schering), $2.5 \mathrm{mg} /$ day i.m. for 3 days before the oestradiol injection; (b) indomethacin, $10 \mathrm{mg} / \mathrm{kg}$ i.m. at the same time as the oestradiol injection; and (c) L11204 (2-(3-ethoxyphenyl)-5, 6-dihydro-s-triazole [5,1- $\alpha$ ] isoquinoline: Lepetit), $100 \mathrm{mg} / \mathrm{kg}$ dissolved in cotton seed oil s.c. 7 days before the oestradiol injection.

In two other groups, rabbits (4 ovariectomized, 3 intact and oestrous) were anaesthetized with pentobarbitone sodium and a polyethylene catheter (i.d. $0.08 \mathrm{~cm}, 0 . d .0 .12 \mathrm{~cm}$ ) was inserted into one uterine vein to the right or left uterine horn at random. Each animal was injected with 2000 units heparin sodium (Upjohn Co.) and the abdomen was closed with sutures. Collection of blood samples was begun 1-2 $\mathrm{h}$ after insertion of the catheter to avoid artefacts related to manipulation of the vein. The blood was collected by suction into a heparinized syringe containing enough indomethacin to give a final concentration of more than $10 \mu \mathrm{g} / \mathrm{ml}$ blood. After sampling, the ovariectomized rabbits were injected with $25 \mu \mathrm{g}$ oestradiol-17 $\beta$ and blood was taken 2,4 and $8 \mathrm{~h}$ later. The intact rabbits were injected $\mathrm{i} . \mathrm{m}$. with $10 \mathrm{mg}$ indomethacin $/ \mathrm{kg}$ and blood was taken at 1,2 and $3 \mathrm{~h}$ after injection. Light anaesthesia was maintained by further injections of pentobarbitone sodium as necessary and the animals were kept warm throughout by being wrapped in towels.

\section{Prostaglandin assays}

The heparinized blood was centrifuged at $500 \mathrm{~g}$ for $20 \mathrm{~min}$ and the plasma was stored at $-20^{\circ} \mathrm{C}$ until assay. PGF and PGE were measured by the double-antibody techniques described by Caldwell, Burstein, Brock \& Speroff (1971), Stylos, Burstein, Rivetz, Gunsalus \& Skarnes (1972) and Stylos, Howard, Ritzi \& Skarnes (1974) with some modifications as described by Harper, Valenzuela \& Hodgson (1978). The frozen plasma was thawed and divided into 2 equal aliquots and 1500 c.p.m. $\left[5,6,8,9,11,12,14,15-{ }^{3} \mathrm{H}(\mathrm{N})\right] \mathrm{PGF}-2 \alpha$ (sp. act. $178 \mathrm{Ci} / \mathrm{mmol}$ : New England Nuclear) or $[5,6,8,11,12,14,-$ $15-{ }^{3} \mathrm{H}$ ]PGE-2 (sp. act. $117 \mathrm{Ci} / \mathrm{mmol}$ ) were added to estimate recovery. Values obtained were corrected for blank values and recovery. A standard of rabbit plasma stripped of endogenous PG by treatment with charcoal and containing $2 \mathrm{ng}$ of the appropriate PG was included in each assay. In the PGF assay, the recoveries ranged from $71 \cdot 5$ to $98.7 \%$ and the $2 \mathrm{ng}$ PGF-2 $\alpha$ standard gave a value of $2 \cdot 5 \mathrm{ng}$. In the PGE assay, the recoveries ranged from $29 \cdot 2$ to $58.6 \%$ (lower than usual) and the 2 ng PGE-2 standard gave a value of $2.52 \mathrm{ng}$. In a series of similar assays the values for $2 \mathrm{ng}$ PGF- $2 \alpha$ and $2 \mathrm{ng}$ PGE-2 have been $2 \cdot 12 \pm 0.05(n=15)$ and $2 \cdot 14 \pm 0.08(n=10)$ respectively. Inter- and intra-assay coefficients of variation were respectively 9.8 and $9.9 \%$ for PGF and 5.0 and $11.6 \%$ for PGE. The sensitivities were $60 \mathrm{pg}$ PGE/tube and $60 \mathrm{pg}$ PGF-2 $\alpha /$ tube.

\section{Statistical analysis}

The results were analysed statistically by a one-way analysis of variance and, if significant differences were seen, then by the method of Student-Newman-Kuels (Sokal \& Rohlf, 1969). Some of the data were also subjected to a linear regression analysis (Texas Instruments Statistics Library Program ST1-08). 


\section{Results}

Both blood flow and perfusion through the uterus increased dramatically by $2 \mathrm{~h}$ after administration of oestradiol (Table 1). At $4 \mathrm{~h}$, blood flow had declined significantly from the peak at $2 \mathrm{~h}$ but was still about 8 -fold greater than the initial control value. No further change was seen between 4 and $8 \mathrm{~h}$ but by $24 \mathrm{~h}$ tissue perfusion, although not total blood flow, had returned to control levels. Despite these dramatic changes in uterine blood flow, blood flow and perfusion through the kidneys in the same animals was unchanged throughout this period, and was much higher than that through the uterus before oestradiol treatment (Table 1).

Table 1. Blood flow (mean \pm s.e.m.) through the uterus and kidneys of ovariectomized rabbits after injection of $25 \mu \mathrm{g}$ oestradiol-17 $\beta$

\begin{tabular}{|c|c|c|c|c|c|}
\hline \multirow[b]{2}{*}{$\begin{array}{c}\text { Hours after } \\
\text { oestradiol }\end{array}$} & \multirow[b]{2}{*}{$\begin{array}{l}\text { No. of } \\
\text { rabbits }\end{array}$} & \multicolumn{2}{|c|}{ Uterus } & \multicolumn{2}{|c|}{ Kidney } \\
\hline & & $\begin{array}{l}\text { Blood flow } \\
\left(\mathrm{ml} \mathrm{min} \mathrm{min}^{-1}\right)\end{array}$ & $\begin{array}{c}\text { Tissue } \\
\text { perfusion } \\
\left(\mathrm{ml} \min ^{-1} \mathrm{~g}^{-1}\right)\end{array}$ & $\begin{array}{l}\text { Blood flow } \\
\left(\mathrm{ml} \mathrm{min} \mathrm{min}^{-1}\right)\end{array}$ & $\begin{array}{c}\text { Tissue } \\
\text { perfusion } \\
\left(\mathrm{ml} \mathrm{min}-1 \mathrm{~g}^{-1}\right)\end{array}$ \\
\hline 0 & 4 & $0.20 \pm 0.05$ & $0.19 \pm 0.02$ & $65 \cdot 31 \pm 7 \cdot 70$ & $3 \cdot 30 \pm 0.18$ \\
\hline 2 & 4 & $7.88 \pm 1.01^{*}$ & $4.13 \pm 0.42^{*}$ & $68.81 \pm 7.43$ & $3.65 \pm 0.50$ \\
\hline 4 & 3 & $1.95 \pm 0.82$ & $1.54 \pm 0.65$ & $58.71 \pm 10.67$ & $3.51 \pm 0.54$ \\
\hline 8 & 3 & $2.78 \pm 1 \cdot 20$ & $1 \cdot 58 \pm 0.60$ & $53.37 \pm 16.03$ & $3 \cdot 10 \pm 0.93$ \\
\hline 24 & 3 & $1.44 \pm 0.41$ & $0.38 \pm 0.16$ & $64.17 \pm 7.95$ & $3.34 \pm 0.41$ \\
\hline
\end{tabular}

\footnotetext{
* Significantly different from all other values in the same column $(P<0.05$, Student-Newman-Kuels test).
}

Blood flow through the uterus at 2 or $12 \mathrm{~h}$ after oestrogen injection was unaffected by pretreatment with progesterone or L11204 or concurrent administration of indomethacin (Table 2). Blood flow through the kidney was not changed by any of these treatments.

PGF values in uterine vein blood were elevated by $2 \mathrm{~h}$ after oestradiol injection, although this increase was not quite significant $(P=0.07)$. Levels at 4 and $8 \mathrm{~h}$ were significantly greater $(P<0.05)$ than that of control, but were not different from the $2 \mathrm{~h}$ value or each other (Table 3). PGE values followed a similar pattern, except that there were no significant differences between any of the PGE values, probably because of the large variation (Table 3 ).

In the oestrous animals, uterine vein blood levels of PGF and PGE were significantly greater $(P<0.05$ and $P<0.05$ respectively) (Table 4) than those of the ovariectomized animals at $0 \mathrm{~h}$ (Table 3). Indomethacin treatment caused a dramatic and significant decline of PGE levels, but although PGF levels declined the means did not differ significantly. Analysis of these data by linear regression showed that the declines of both PGF and PGE with time were significant (PGF: $r=0 \cdot 60, n=12$, $P<0.05$; PGE: $r=0.75, n=12, P<0.01$ ).

\section{Discussion}

The fact that blood fiow through the uterus increases after oestrogen injection has been previously observed for sheep (Killam, Rosenfeld, Battaglia, Makowski \& Meschia, 1973; Rosenfeld et al., 1973; Abrams \& Sharp, 1977). In conscious ovariectomized sheep, a maximal effect on uterine blood flow was observed with a dose of $0.5 \mu \mathrm{g}$ oestradiol-17ß/kg intra-arterially, and this occurred at $2 \mathrm{~h}$; the effect was still observable $12 \mathrm{~h}$ after injection. Doses up to $10 \mu \mathrm{g}$ oestradiol- $17 \beta / \mathrm{kg}$ produced no greater effect than $0.5 \mu \mathrm{g} / \mathrm{kg}$ (Still \& Greiss, 1976).

Previously reported values for blood flow through the rabbit uterus are $0.588 \pm 0.171 \mathrm{ml} \mathrm{min}^{-1} \mathrm{~g}^{-1}$ tissue (Dickson, Waldhalm \& Amend, 1974) and $0.910 \pm 0.253 \mathrm{ml} \mathrm{min}^{-1} \mathrm{~g}^{-1}$ (Waldhalm \& Dickson, 1976) in oestrous rabbits when measured by a hydrogen gas technique and $\mathbf{0 . 7 5}+\mathbf{0 . 0 6} \mathbf{m l}_{\mathrm{D}} \mathbf{m i n}_{04}^{-1} \mathbf{g}_{23}^{-1}$ 
R. Antonini et al.

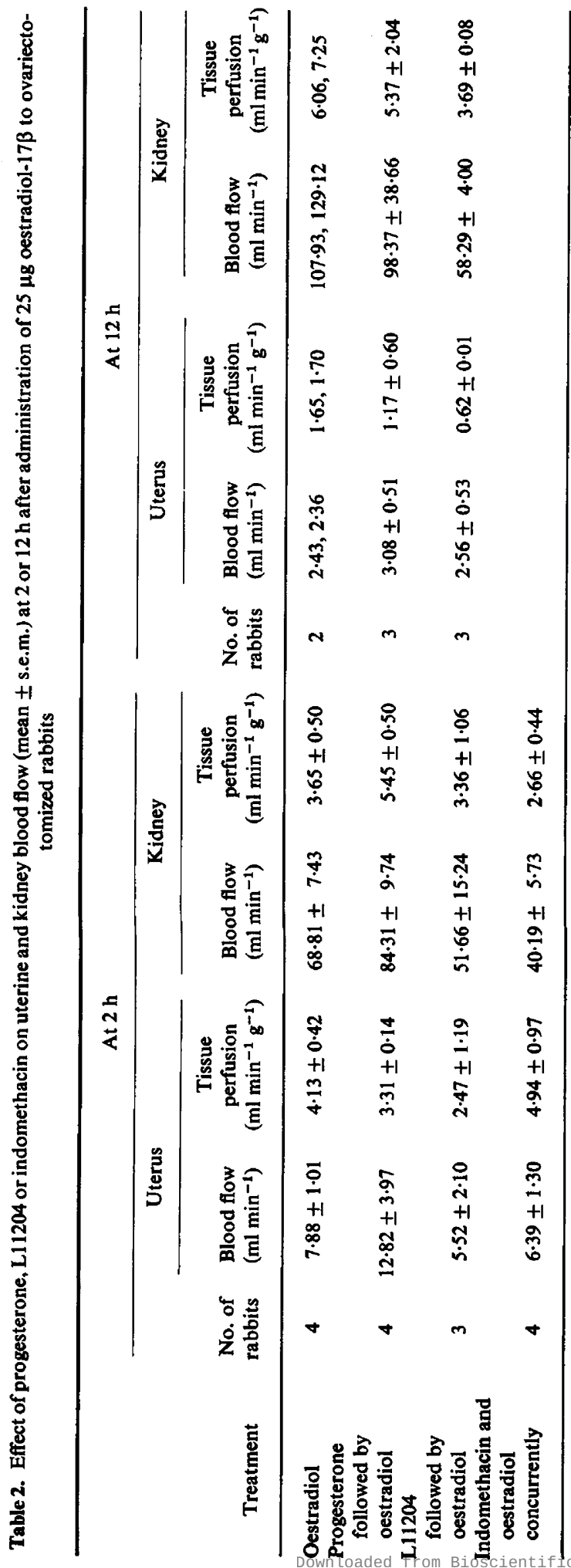


Table 3. Concentrations (mean \pm s.e.m.) of PGF and PGE in uterine vein blood of ovariectomized rabbits after injection of $25 \mu \mathrm{g}$ oestradiol-17 $\beta$

\begin{tabular}{ccccc}
\hline $\begin{array}{c}\text { Time after } \\
\text { oestradiol } \\
(\mathrm{h})\end{array}$ & $\begin{array}{c}\text { No. of } \\
\text { rabbits }\end{array}$ & $\begin{array}{c}\text { PGF } \\
(\mathrm{ng} / \mathrm{ml})\end{array}$ & $\begin{array}{c}\text { PGE } \\
(\mathrm{ng} / \mathrm{ml})\end{array}$ & $\begin{array}{c}\text { PGF:PGE } \\
\text { ratio }\end{array}$ \\
\hline 0 & 4 & $0.52 \pm 0.21$ & $0.74 \pm 0.51$ & 0.71 \\
2 & 4 & $1.74 \pm 0.51$ & $3.25 \pm 1.96$ & 0.54 \\
4 & 4 & $1.86 \pm 0.36^{*}$ & $3.23 \pm 2.50$ & 0.58 \\
8 & 4 & $2.03 \pm 0.27^{*}$ & $2.42 \pm 0.60$ & 0.84 \\
\hline
\end{tabular}

* Significantly different from value at $0 \mathrm{~h}(P<0.05$, Student-Newman-Kuels test $)$.

Table 4. Concentrations (mean \pm s.e.m.) of PGF and PGE in uterine vein blood of intact oestrous rabbits after injection of $10 \mathrm{mg}$ indomethacin $/ \mathrm{kg}$

\begin{tabular}{ccccc}
\hline $\begin{array}{c}\text { Time after } \\
\text { indomethacin } \\
\text { (h) }\end{array}$ & $\begin{array}{c}\text { No. of } \\
\text { rabbits }\end{array}$ & $\begin{array}{c}\text { PGF } \\
(\mathrm{ng} / \mathrm{ml})\end{array}$ & $\begin{array}{c}\text { PGE } \\
(\mathrm{ng} / \mathrm{ml})\end{array}$ & $\begin{array}{c}\text { PGF: PGE } \\
\text { ratio }\end{array}$ \\
\hline 0 & 3 & $1.84 \pm 0.40$ & $2.34 \pm 0.30$ & 0.79 \\
1 & 3 & $0.71 \pm 0.21$ & $0.35 \pm 0.22^{*}$ & 2.03 \\
2 & 3 & $0.60 \pm 0.27$ & $0.10 \pm 0.01^{*}$ & 6.00 \\
3 & 3 & $0.51 \pm 0.31$ & $0.10 \pm 0.01^{*}$ & 5.10 \\
\hline
\end{tabular}

* Significantly different from value at $0 \mathrm{~h}(P<0.05$, Student-Newman-Kuels test).

with radioactive microspheres (Blasco, Wu, Flickinger, Wheeler \& Mikhail, 1973). The control values observed in the present experiments are lower than these, presumably because the animals had been ovariectomized. However, the values that we observed for blood flow through the kidneys are not different from those given by Janson (1975). Similar values, both for total rate of blood flow to the uterus and for uterine perfusion, have been recorded in oestrous guinea-pigs (Sjöquist, Bjellin \& Carter, 1977). We are therefore confident that our uterine blood flow values are valid.

In the present experiments, the dose of oestradiol used ( $25 \mu \mathrm{g} / \mathrm{rabbit}$, approximately $5 \cdot 6-7 \cdot 1 \mu \mathrm{g} / \mathrm{kg}$ ) was chosen because it is known to affect ovum transport (Saksena \& Harper, 1975). Although this dose of oestradiol is in the pharmacological range, the observations of Still \& Greiss (1976) indicate that our results for blood flow should not be different from those induced by more physiological doses of oestrogen. The decline observed by us is similar to that reported by Still \& Greiss (1976), but no direct comparison is possible since these authors give no absolute values, only percentage change from controls.

Blood flow through the kidney was unaffected by oestrogen treatment in the ovariectomized rabbits. Similarly, Janson (1975) showed that LH, while causing an increased blood flow through the ovaries of intact rabbits, did not affect kidney blood flow.

Although PGE and PGF concentrations in uterine vein blood were elevated at $2 \mathrm{~h}$ after oestrogen injection, concomitant with the increased ovarian blood flow, the levels were still elevated at 4 and $8 \mathrm{~h}$ when blood flow was declining. Castracane \& Jordan (1975) observed that, in uterine vein blood of ovariectomized rats pretreated with progesterone and injected with $10 \mu \mathrm{g}$ oestradiol-17 $(50-66 \cdot 7$ $\mu \mathrm{g} / \mathrm{kg}$ ), PGE peaked at 1-2 h, declined at $4 \mathrm{~h}$ and was elevated again at $8 \mathrm{~h}$, while PGF increased steadily up to $12 \mathrm{~h}$. The pattern of changes in PG concentration that we observed in rabbits was similar to these, but not to those seen in sheep with autotransplanted uteri and infused intraarterially with oestrogen (Barcikowski et al., 1974). These differences are unlikely to be due to the 
effect of anaesthesia since Bruce \& Gibbs (1976) have shown that, despite major differences in cardiac output, arterial $\mathrm{PO}_{2}, \mathrm{PCO}_{2}, \mathrm{pH}$ and base status, ovarian blood flow was similar in conscious and anaesthetized animals. Ovarian blood flow could, however, be influenced by the method of cannulation of the vein, because other studies have shown that catheterization of a vein can, depending on technique, substantially alter blood flow through the vein (Hilliard \& Eaton, 1971; Shaikh \&. Harper, 1972). In the present experiments, therefore, no good correlation existed between increased blood flow and PG concentrations.

When indomethacin was used to inhibit PG synthesis, there was a progressive reduction of PGE and PGF values in uterine vein blood of oestrous rabbits although the basal levels were not different from those observed in the ovariectomized animals at 2, 4 or $8 \mathrm{~h}$ after oestrogen treatment (Tables 3 and 4). However, uterine blood flow was not affected by the indomethacin treatment (Table 2) although uterine blood flow is greater in untreated oestrous rabbits (Blasco et al., 1973; Waldhalm \& Dickson, 1976) than in ovariectomized ones (present study).

The drug L11024 is known to interfere with metabolism of PGs and is thought to produce its antifertility effect by this mechanism (Lerner \& Carminati, 1977). Its effect on PG metabolism is not seen until $48 \mathrm{~h}$ after administration and can be present up to 10 days after one treatment. A maximal effect is produced in rats by $50 \mathrm{mg} / \mathrm{kg}$ given subcutaneously (Lerner \& Carminati, 1977). We therefore used this compound to determine whether an elevation of endogenous PG levels, as opposed to a depression, might affect uterine blood flow. No effect of this treatment was observed.

The experiment with progesterone followed by oestrogen treatment was carried out because this schedule can enhance the elevation of PGs in uterine tissue and venous blood usually observed after oestrogen treatment (Blatchley et al., 1971; Blatchley, Donovan, Horton \& Poyser, 1972; Saksena \& Harper, 1972; Saksena \& Lau, 1973; Blatchley \& Poyser, 1974; Castracane \& Jordan, 1975; Ham, Cirillo, Zanetti \& Kuehl, 1975). This treatment also failed to influence the response of blood flow to oestrogen.

PGFs are reported not to alter significantly uterine vascular resistance, while PGEs are potent uterine vasodilators (Clark, Ryan \& Brody, 1973, 1976). The oestrogen-induced increase in uterine blood volume of rats is associated with increased amounts of both PGF and PGE in the uterus and there is a correlation between the magnitude of inhibition of PG synthesis by meclofenamic acid or indomethacin and the ability of the uterus to respond to oestrogen (Ryan et al., 1974). Sharma \& Garg (1977) found increased uterine concentrations of PGE and PGF in ovariectomized rats treated with oestradiol-17 $\beta$. A maximal response was observed with 2 doses of approximately $10 \mu \mathrm{g} / \mathrm{kg}$ given $24 \mathrm{~h}$ apart. Some increase in PGs in uterine fluid was also observed. The PGF:PGE ratios were greater than one for uterine tissue and less than one for uterine fluid. In the present experiments, although the PGF:PGE ratios in uterine vein blood were also less than one, a relationship between elevated PGE production and increased uterine blood flow was not confirmed. However, indomethacin and sodium meclofenamate have been reported to reduce slightly, but significantly, the renal blood flow in conscious (Beilin \& Bhattacharya, 1977) and anaesthetized rabbits (Larsson \& Änggård, 1974). A slight, but not significant, decline in renal blood flow was also seen in the present experiments.

We thank Dr J. E. Pike, Upjohn Co., for the gifts of prostaglandins; Merck, Sharp and Dohme for the gift of indomethacin; Dr L. J. Lerner, Gruppo Lepetit, for the gift of L11204; and Elizabeth Menchaca for technical assistance. The work was supported by the Rockefeller Foundation (R.A. and G.V. were Rockefeller Foundation Postdoctoral Fellows in Reproductive Biology) and W.H.O. (Contract S75373).

\section{References}

Abrams, R.M. \& Sharp, D.C. (1977) Heat flow technique for estimating uterine blood flow. Biol. Reprod. 16, 281-285.

Barcikowski, B., Carlson, J.C., Wilson, L. \&
McCracken, J.A. (1974) The effect of endogenous and exogenous estradiol-17 $\beta$ on the release of prostaglandin $\mathbf{F}_{2 x}$ from the ovine uterus. Endocrinology $95,1340-1349$. 
Beilin, L.J. \& Bhattacharya, J. (1977) The effect of prostaglandin synthesis inhibitors on renal blood flow distribution in conscious rabbits. J. Physiol., Lond. 269, 395-405.

Blasco, L., Wu, C.H., Flickinger, G.L., Wheeler, J. \& Mikhall, G. (1973) Blood flow to the reproductive organs of the estrus rabbit. Gynecol. Invest. 4, 270276.

Blatchley, F.R. \& Poyser, M.L. (1974) The effect of oestrogen and progesterone on the release of prostaglandins from the uterus of the ovariectomized guinea-pig. J. Reprod. Fert. 40, 205-209.

Blatchley, F.R., Donovan, B.T., Poyser, N.L., Horton, E.W., Thompson, C.J. \& Los, M. (1971) Identification of prostaglandin $F_{2 a}$ in the uteroovarian blood of guinea-pigs after treatment with oestrogen. Nature, Lond. 230, 234-244.

Blatchley, F.R., Donovan, B.T., Horton, E.W. \& Poyser, N.L. (1972) The release of prostaglandins and progestin into the utero-ovarian venous blood of guinea-pigs during the oestrous cycle and following oestrogen treatment. J. Physiol., Lond. 223, 69-88.

BrUCE, N.W. \& GibBs, C.P. (1976) Ovarian blood flow in conscious and anesthetized pregnant rabbits near term and the influence of arterial blood gas tensions. J. Reprod. Fert. 47, 343-345.

Caldwell, B., Burstein, S., Brock, W. \& Speroff, L. (1971) Radioimmunoassay of the $F$ prostaglandins. J. clin. Endocr. Metab. 33, 171-175.

Caldwell, B.V., Tillson, S.A., Brock, W.A. \& SPEROFF, L. (1972) The effects of exogenous progesterone and estradiol on prostaglandin $F$ levels in ovariectomized ewes. Prostaglandins 1, 217-228.

Castracane, V.D. \& Jordan, V.C. (1975) The effect of estrogen and progesterone on uterine prostaglandin biosynthesis in the ovariectomized rat. Biol. Reprod. 13, 587-596.

Clark, K.E., Ryan, M.J. \& Brody, M.J. (1973) Effect of prostaglandin $E_{1}$ and $F_{2 \alpha}$ on uterine hemodynamics and motility. Adv. Biosci. 9, 779-782.

Clark, K.E., Ryan, M.J. \& Brody, M.J. (1976) Effect of prostaglandins on vascular resistance and adrenergic venoconstrictor responses in the canine uterus. Prostaglandins 12, 71-82.

Chang, M.C. (1966) Effects of oral administration of medroxyprogesterone acetate and ethinyl estradiol on the transportation and development of rabbit eggs. Endocrinology 79, 939-948.

Chang, M.C. \& Harper, M.J.K. (1966) Effects of ethinyl estradiol on egg transport and development in the rabbit. Endocrinology 78, 860-872.

Chang, M.C. \& Yanagimachi, R. (1965) Effect of estrogens and other compounds as oral antifertility agents on the development of rabbit ova and hamster embryos. Fert. Steril. 16, 281-291.

Dickson, W.M., Waldhalm, S.J. \& Amend, N. (1974) Blood flow to the oviduct of the non-pregnant rabbit. Biol. Reprod. 10, 335-345.

GREENWALD, G.S. (1963) Interruption of early pregnancy in the rabbit by a single injection of oestradiol cyclopentylpropionate $J$. Endocr. 26, 133-138.

GreENWALD, G.S. (1967) Species differences in egg transport in response to exogenous estrogen. Anat. Rec. 157, 163-172.
Ham, E.A., Cirillo, V.J., Zanetti, M.E. \& Kuehl, F.A., JR (1975) Estrogen directed synthesis of specific prostaglandins in uterus. Proc. natn. Acad. Sci. U.S.A. 72, 1420-1424.

Harper, M.J.K., Valenzuela, G. \& Hodgson, B.J. (1978) Accelerated ovum transport in rabbits induced by endotoxin. 1. Changes in prostaglandin levels and reversal of endotoxin effects. Prostaglandins 15, 4363.

Hilliard, J. \& Eaton, L.W., JR (1971) Estradiol-17ß,

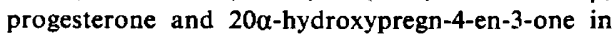
rabbit ovarian venous plasma. II. From mating through implantation. Endocrinology 89, 522-527.

JANSON, P.O. (1975) Effects of luteinizing hormone on blood flow in the follicular rabbit ovary, as measured by radioactive microspheres. Acta endocr., Copenh. 79, 122-133.

Killam, A.P., Rosenfeld, C.R., Battaglia, F.C., MaKowski, E.L. \& Meschia, G. (1973) Effect of estrogens on the uterine blood flow of oophorectomized ewes. Am. J. Obstet. Gynec. 115, 1045-1052.

LaRsson, C. \& ÄNGGARD, E. (1974) Increased juxtamedullary blood flow on stimulation of intrarenal prostaglandin biosynthesis. Eur. J. Pharmac. 25, 326-334.

LeRner, L.J. \& Carminati, P. (1977) Effect of day of pregnancy and pregnancy terminating agents on prostaglandin synthesis and metabolism and histamine metabolism in the rat utero-placental fetal complex and lung. J. Steroid Biochem. 8, 395-402.

Rosenfeld, C.R., Killam, A.P., Battaglia, F.C., Makowski, E.L. \& Meschia, G. (1973) Effect of estradiol-17 $\beta$ on the magnitude and distribution of uterine blood flow in non-pregnant oophorectomized ewes. Pediatr. Res. 7, 139-148.

Ryan, M.J., Clark, K.E., Van Orden, D.E., Farlfy, D., EdvinsSON, L., SJöBerg, N.-O., VAN ORden, L.S. \& BRODY, M.J. (1974) Role of prostaglandins in estrogen-induded hyperemia. Prostaglandins 5, 257268.

Saksena, S.K. \& Harper, M.J.K. (1972) Levels of F prostaglandin (PGF) in uterine tissue during the estrous cycle of the hamster: effects of estradiol and progesterone. Prostaglandins 2, 405-411.

SaKsena, S.K. \& HarPer, M.J.K. (1975) Relationship between concentration of prostaglandin $F(P G F)$ in the oviduct and egg transport in rabbits. Biol. Reprod. 13, 68-67.

SaKSENA, S.K. \& LaU, I.F. (1973) Effect of exogenous estradiol and progesterone on the uterine tissue levels of prostaglandin $\mathrm{F}_{2 \alpha}\left(\mathrm{PGF}_{2 \alpha}\right)$ in ovariectomized mice. Prostaglandins 3, 317-322.

SHAIKH, A.A. \& HARPER, M.J.K. (1972) Ovarian steroid secretion in estrous, mated and hCG-treated rabbits, determined by concurrent cannulation of both ovarian veins. Biol. Reprod. 7, 387-397.

Sharma, S.C. \& GarG, S.K. (1977) Measurement of prostaglandins $E$ and $F$ in the uterine tissue and uterine fluid of ovariectomized rats treated with various doses of oestradiol-17ß.J. Reprod. Fert. 51, 119-121.

SJöQuist, P.-O.B., BJellin, L. \&. CARTer, A.M. (1977) Blood flow to the genital tract of oestrous and dioestrous guinea-pigs. $J$. Reprod. Fert, 51, 83-86, 
SoKal, R.R. \& RoHLP, F.J. (1969) Biometry, pp. 239246. W. H. Freeman \& Co., San Francisco.

STILL, J.G. \& GREISs, F.C. (1976) Effect of cis- and transclomiphene on the uterine blood flow of oophorectomized ewes. Gynecol. Invest. 7, 187-200.

Stylos, W.A., Burstein, S., Rivetz, B., Gunsalus, P. \& SKarNes, R.C. (1972) The production of anti-F prostaglandin serum and its use in radioimmunoassay. Intra-Science Chem. Rep. 6, 67-71.
Stylos, W.A., Howard, L., Ritzi, E. \& Skarnes, R. (1974) The preparation and characterization of prostaglandin $\mathrm{E}_{1}$ antiserum. Prostaglandins 6, 113.

Waldhalm, S.J. \& Dickson, W.M. (1976) Blood flow to the uterine tube (oviduct) of the early pregnant and pseudopregnant rabbit. Am.J. vet. Res. 37, 817-821.

Received 22 March 1978 